\title{
IS THE GLOBAL COMPETITIVENESS INDEX INFORMATIVE?
}

\author{
Menbere Workie Tiruneh${ }^{1}$, Edita Hekelová ${ }^{2}$
}

\begin{abstract}
This paper critically discusses whether, and to what extent, the Global Competitiveness Index (GCI) compiled by the World Economic Forum is informative, given the cross-positive effect across indicators that involve ranking of countries. The results suggest positive cross-effects between sub-indices for a group of economies in the European Union (EU) and other certain advanced economies. Economies with an advanced level of higher education and training, and a superior level of innovation, tend to experience a higher level of ranking in the global competitiveness index compared to countries with lower levels of education and innovation. The results of this study for a group of 28 EU member states during 2007-2015 reveal a heterogonous position of the EU member states despite their obvious achievement of converging income-percapita in the same period. However, the results also indicate potential methodological inconsistencies in terms of the ranking of countries, relating to a common problem in economics, known as endogeneity or reverse causality, and based on variables that, statistically, appeared significantly correlated to each other.
\end{abstract}

JEL Classification: 011, 047, P51, DOI: http://dx.doi.org/10.12955/cbup.v4.754

Keywords: competitiveness, endogeneity, Global Competitiveness Index.

\section{Introduction}

The role of comparative and competitive advantages belongs to one of the most important determinants of long-running economic growth. The discussion has been evolving both over time and across countries, and has been the center of economic theory as well as policy making. With the intensity of globalization in international trade and relatively free global capital mobility, there has been a shift away from the concept of comparative advantage towards a more comprehensive concept of competitive advantage. The debate is far from being exhaustively concluded as there remains disagreements and open issues among economists in understanding what exactly defines competitiveness and how it should be measured, mainly on a national level.

There is almost a clear consensus, in regard to competitiveness on a firm or industry level, as it is considered the foundation of competitiveness. As pointed out by Porter (1990, p. 6), competitiveness on a national level is difficult to define, although it is straightforward at the firm level, where firms compete among each other in terms of market share in a particular industry or territory and the payoffs from competitiveness are measured in terms of profitability and rate of return (Lall, 2001). Nonetheless, given the intensity of global trade in goods and services and the corresponding global capital mobility, the need to measure competitiveness on a national level has also increased over the past several decades.

In this paper, we discuss whether the ranking of a country's competitiveness would be feasible, based on variables that are significantly correlated. In addition, this study examines the evolution of this ranking, mainly on scores rather than the ranking orders of the pre- and post-global financial crisis periods. We use long-term time series data for the global competitiveness index (GCI) for insight about the dynamics of the GCI, both over time and across countries.

This paper is structured as follows: the following section discusses the concept of competitiveness. The next involves empirical discussion on the GCI scores and the pillars and sub-indices that form the GCI, and attempts to answer the question of whether the GCI could be informative, given the scale of endogeneity across variables that make up the GCI. The last section provides the conclusion.

\section{The Concept of Competitiveness: Literature Review}

As indicated above, there is no clear definition of competitiveness on a national level and this is reflected in differences in the competiveness rankings of countries by various organizations, such as the International Institute for Management Development (IMD) and Global Competitiveness Index

\footnotetext{
1 Menbere Workie, College of Management, Vysoká škola manažmentu (VSM), Bratislava and Institute of Economic Research, Slovak Academy of Sciences, Bratislava, mworkie@vsm.sk, menbere.workie@savba.sk

${ }^{2}$ Edita Hekelová, College of Management, Vysoká škola manažmentu (VSM), Bratislava, ehekelova@vsm.sk
} 
(Lall, 2001). Similarly, as Frenkel, Koske, and Swonke (2003) showed, there is also a significant difference (at least for several countries) in the ranking of the European Union (EU) member states, and other advanced and emerging economies, using the Microeconomic Competitiveness Index (MICI) and Global Competitiveness Index (GCI) that are compiled by the World Economic Forum. The difficulties of measuring competitiveness on a national level do not justify, however, the ranking of competitiveness on a national level being disregarded. While Porter (1990) recognized that the significance of innovation and product upgrading to country-level competitiveness, he emphasized that the pressure of global competition emphasized the importance of recognizing competition on a country level.

There are a number of interesting questions to be raised here. First, what does it mean for a country to be ranked first, versus last? Second, if a country is ranked first, does it mean it is the best country in every dimension? Finally, what is the quality of data and the subsequent confidence we have about the ranking of countries? These questions are partly answered by referring to Porter's $(1990$, p. 3) study, where he stressed the realization that no nation is globally competitive in every industry, and this reflects, among other factors, the differences in the quality of institutions, cultural heritage, economic structure, and national values. This is also a reminder of the multifaceted nature of competitiveness of a national level, which ranges from competitiveness on export, exchange rate, macroeconomic stability (proxied by inflation) and internal and external balances, just to mention a few (MacArthur and Sachs, 2002; Barro, 2003).

Therefore, competitiveness on a national level needs certain clarity. Porter (1990) argued that "the variable that best describes competitiveness on the national level is productivity" (p.6). This is also reflected in the definition of competitiveness by the World Economic Forum that describes global competitiveness index "as a set of institutions, policies, and factors that determine the level of productivity of a country, conditions of public institutions and technical conditions" (Blanke, and Sala-i-Martin, 2009, p. 3). Likewise, Krugman (1994) described competitiveness, on the national level,"as a funny way saying "productivity" and would have nothing to do with international competition" (p. 32). . Likewise, Sala-i-Martin, et al (2009) emphasize that "the concept of competitiveness thus involves static and dynamic components: although the productivity of a country clearly determines its ability to sustain a high level of income, it is also one of the central determinants of the returns to investment, which is one of the key factors explaining an economy's growth potential" (p.3).

Considering productivity as a gross proxy for competitiveness on the national level, a better understanding is needed of the sources of cross-country variation in productivity and economic growth that ultimately determines living standards of nations. There are competing theories that explain the sources of cross-country variation in productivity and economic growth. The neoclassical model of economic growth argues that productivity is the source of exogenous technological progress, and by implication, that explains why some countries are rich while other countries are poor.

Regarding the neoclassical model there is debate as to whether nations can be successful in innovation and technological progress without being successful in human capital accumulation. This debate prompted the emergence of alternative theories to better understand the sources of cross-country variations in productivity and economic growth. A widely recognized theory is the endogenous growth model, which recognizes the role of innovation and human capital in the growth process. Lucas (1988) outlined that human capital is an essential part of technological progress, and hence, shifted the line of debate in understanding the sources of productivity towards human capital accumulation. Romer (1990) argued along similar lines. While recognizing the pivotal role of technological advancement to economic growth and productivity, he acknowledged that technological change is the result of human capital accumulation, and hence, advocated the endogenous nature of technological progress in line with the endogenous theory. Mankiw, Romer, and Weil (1992) empirically studied the determinants of economic growth and augmented the value of human capital in the Solow model to show the significantly decreasing role of physical capital accumulation once human capital is incorporated. Earlier studies, for example Nelson and Phelps (1966), emphasized the role of education in technological advancement, arguing that "educated people make good innovators, so that education speeds the process of technological diffusion" (p.3). 


\section{Methodology and Data Compilation}

In this paper, we analyzed data of the global competitiveness index scores of the European Union (EU) member states, during the 2006-2007 to 2014-2015 ranking periods. Our analysis was, therefore, based on a group of $28 \mathrm{EU}$ member states. The source of all data was the World Economic Forum, Global Competitiveness Index database. While we recognized certain countries, such as Bulgaria, Romania, and Croatia, had joined the EU in 2009 (Bulgaria and Romania) and in 2013 (Croatiait did not preclude us from considering data of all EU member states for the entire period. Our study examined the EU competitiveness scores from two perspectives. First, we checked for the evolution of overall ranking, while considering the impact of the global financial crisis. In this step, we also included certain OECD member states and emerging economies (such as China) to reflect the position of EU members in a broader context. We then checked for the evolution of EU members' competitiveness as scores based on aggregate pillars (basic requirement, efficiency enhancers, and innovation and sophistication factors). Finally, we considered a broader set of pillars (pillar one through to pillar twelve) while emphasizing the cross-effects or possible endogeneity problem across the pillars that comprised the global competitiveness scores.

The main factors that formed the global competitiveness index are summarized in Table 1. As shown in the table, there were basically three pillars (basic requirements, efficiency enhancers, and innovation and sophistication factors) that determined the countries' competitive advantage. Each pillar consisted of several other indicators that were indispensable in terms of achieving and sustaining the level of competitiveness (Workie Tiruneh, \& Griffin, 2015).

Table 1: Sub-indices of the Global Competitiveness Index

\begin{tabular}{|c|c|c|c|}
\hline Pillars & Basic Requirements & Efficiency Enhancers & $\begin{array}{c}\text { Innovation } \\
\text { and } \\
\text { Sophistication } \\
\text { Factors }\end{array}$ \\
\hline \multirow{5}{*}{ Variables } & Infrastructure & Goods Market Efficiency & $\begin{array}{c}\text { Business } \\
\text { Sophistication }\end{array}$ \\
\hline & Macroeconomic Environment & Labor Market Efficiency & Innovation \\
\hline & Health and Primary Education & $\begin{array}{c}\text { Financial Market } \\
\text { Development }\end{array}$ & \\
\hline & & Technological Readiness & \\
\hline & & Market Size & \\
\hline
\end{tabular}

An interesting aspect of analyzing the global competitiveness index was the potential impact of the global financial crisis. The ranking for pre-crisis years clearly showed that advanced economies, such as the United States and Switzerland, dominated the ranking, followed by other western European economies. As the crisis deepened (2010 and beyond), the United States (US) lost its competitive advantage and other countries, notably, Switzerland and Scandinavian countries, became the leaders (Workie, Tiruneh, \& Griffin, 2015). The differences in global competitiveness ranking is more remarkable when one compares the crisis period against the "post-crisis" period, where the United States, for instance, moved from the first place in 2008-2009 to fourth place in 2011-2012 and to seventh place in 2012-2013, while Switzerland progressed to take over the top position, previously held by the US (Figure 1).

As shown in Figure 1, the impact of the global financial crisis (the Great Recession) on the ranking of countries suggests there were cross-country variations in terms of coping with the crisis. Some countries managed to sustain or even improve their position in the ranking, such as Switzerland, Finland, Germany, Japan, United Kingdom (UK), the Netherlands, Austria, Poland, and Norway. 
Others lost their competitive position in the aftermath of the financial crisis compared with the precrisis period, such as Slovakia, Slovenia, and Greece.

Figure 1: The evolution of scores before and after the financial crisis
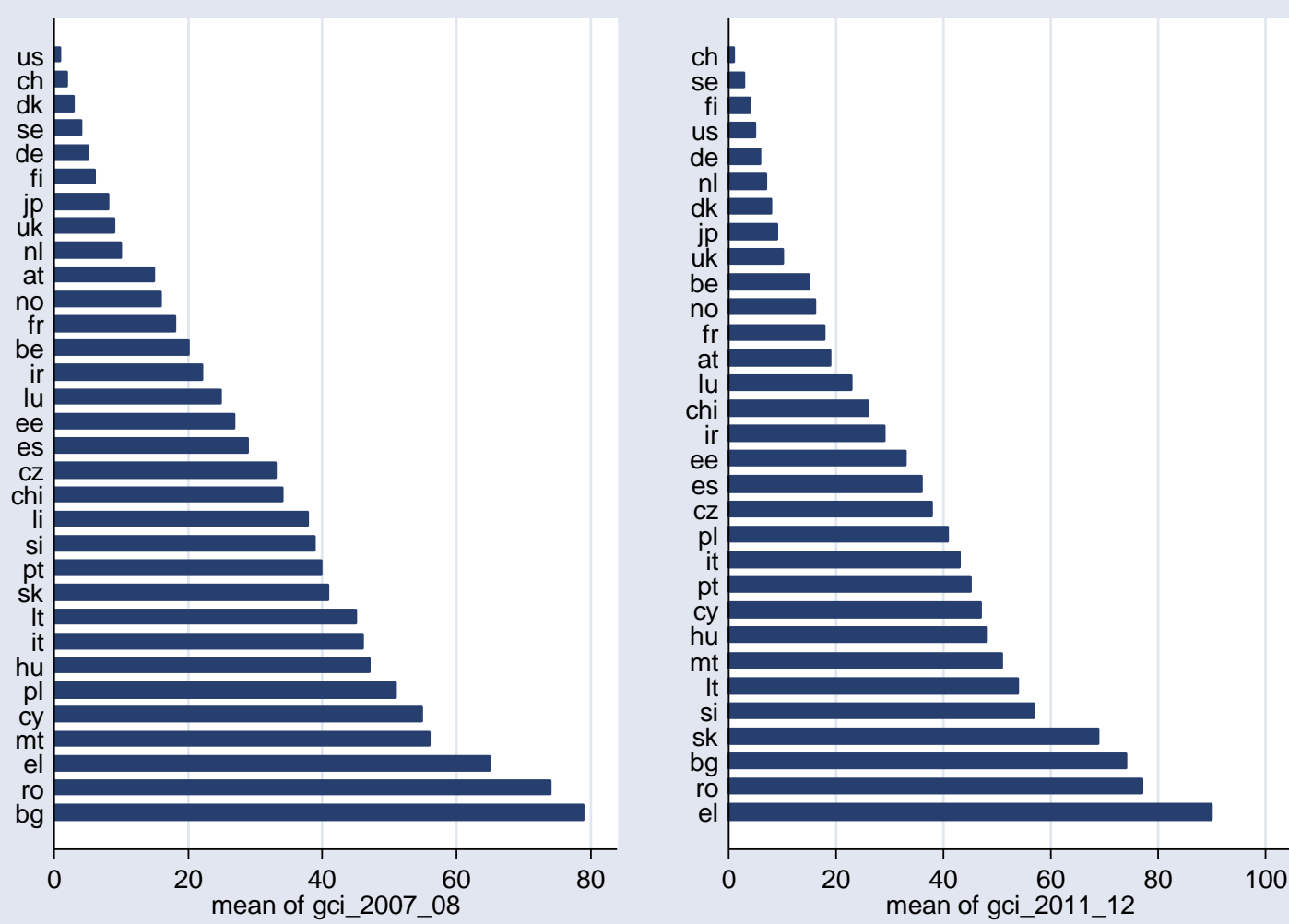

us: Unites States, ch: Switzerland, dk: Denmark, se: Sweden, de: Germany, fi: Finland, jp: Japan, uk: United Kingdom, nl: The Netherlands, at: Austria, no: Norway, fr: France, be: Belgium, ir: Ireland, lu: Luxemburg, ee: Estonia, es: Spain, cz: Czech Republic, chi: China, li: Latvia, si: Slovenia, pt: Portugal, sk: Slovakia, lt: Lithuania, it: Italy, hu: Hungary, pl: Poland, cy: Cyprus, mt: Malta, el 9greece, ro: Romania, and bg: Bulgaria).

Source: World Economic Forum, Global Competitiveness database (2015-2016)

\section{The Competitiveness Position of EU Member States: Some Stylized Facts and Analysis}

Despite the remarkable convergence in real income per capita in the past 15 years or so, the EU remained significantly heterogeneous in terms of its competitiveness scores. Examining the World Economic Forum (WEF) GCI score for the most recent period (2014-2015) and the most distant period (2006-2007), it becomes apparent that the countries with the highest scores in the GCI in 2006-2007 were, to a large extent, the same countries that had the highest scores in the most recent period (2014-2015). This coincidence signaled divergence rather than convergence. As is depicted from Figure 2, most new EU member states recorded ranks in the lowest order for both periods, while most advanced member state of the EU successfully sustained their position.

Figure 2 somewhat shows two clusters of economies: 1) new EU member states with the lowest GCI scores and 2) advanced economies with the highest scores. Nonetheless, this depiction does not mean that the new EU member states stagnated or that they were homogenous as conversely, there were vital differences among new member states themselves. Figure 3 shows the countries that had improvements and those that had deteriorating positons in the GCI scores during the 2015-2016 ranking compared to the 2006-2007 ranking period. 
Figure 2: The evolution of GCI in the European Union (2014-2015 against 2006-2007)

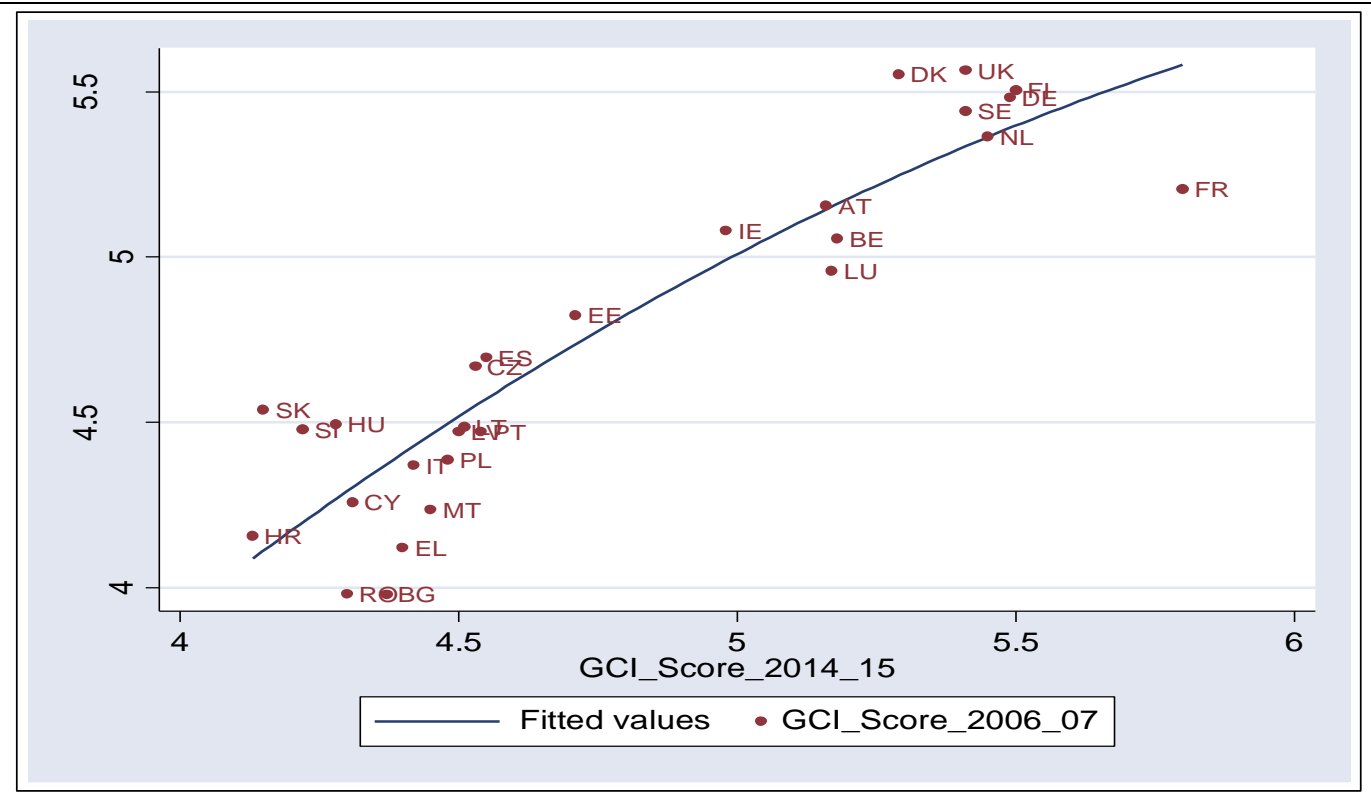

Source: Authors' comupations based on the the World Economic Forum, Global Competitiveness database 2015-2016

Figure 3: Difference in Global Competitiveness Index GCI score between 2014-2015 and 20062007
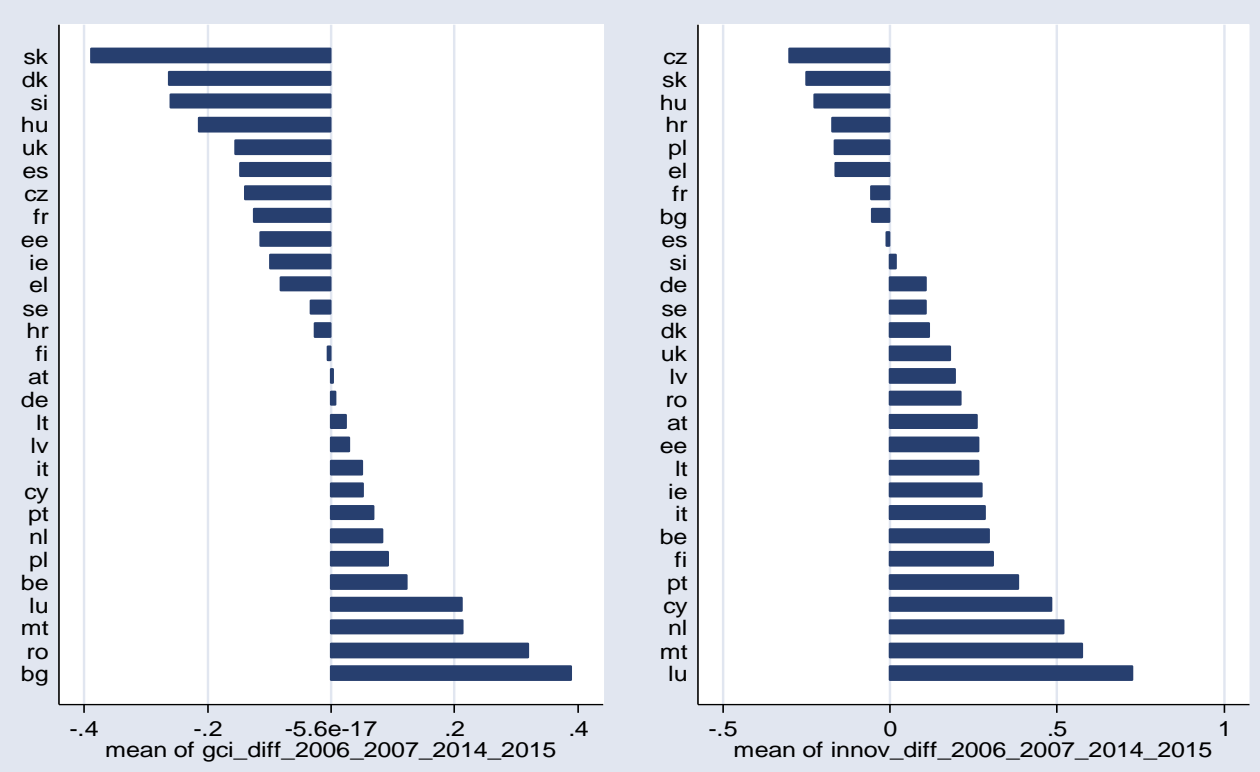

Source: Authors' computations based on the World Economic Forum, Global Competitiveness database 2015-2016

The highest level of divergence persisted in innovation and sophistication factors among EU member states. Considering all twelve pillars (Figure 4) revealed the followingsee, figure 4):

- Most countries that progressed in basic requirements involved the new EU member states, implying that these economies were predominantly considered factor-driven. 
- New member states had managed to narrow their gap in higher education and training (HET), general market efficiency (GME), and labor-market efficiency (LME).

- Most new EU members lagged behind in innovation and sophistication factors.

Figure 4: Standard deviation in the Global Competitiveness Index (GCI) pillars

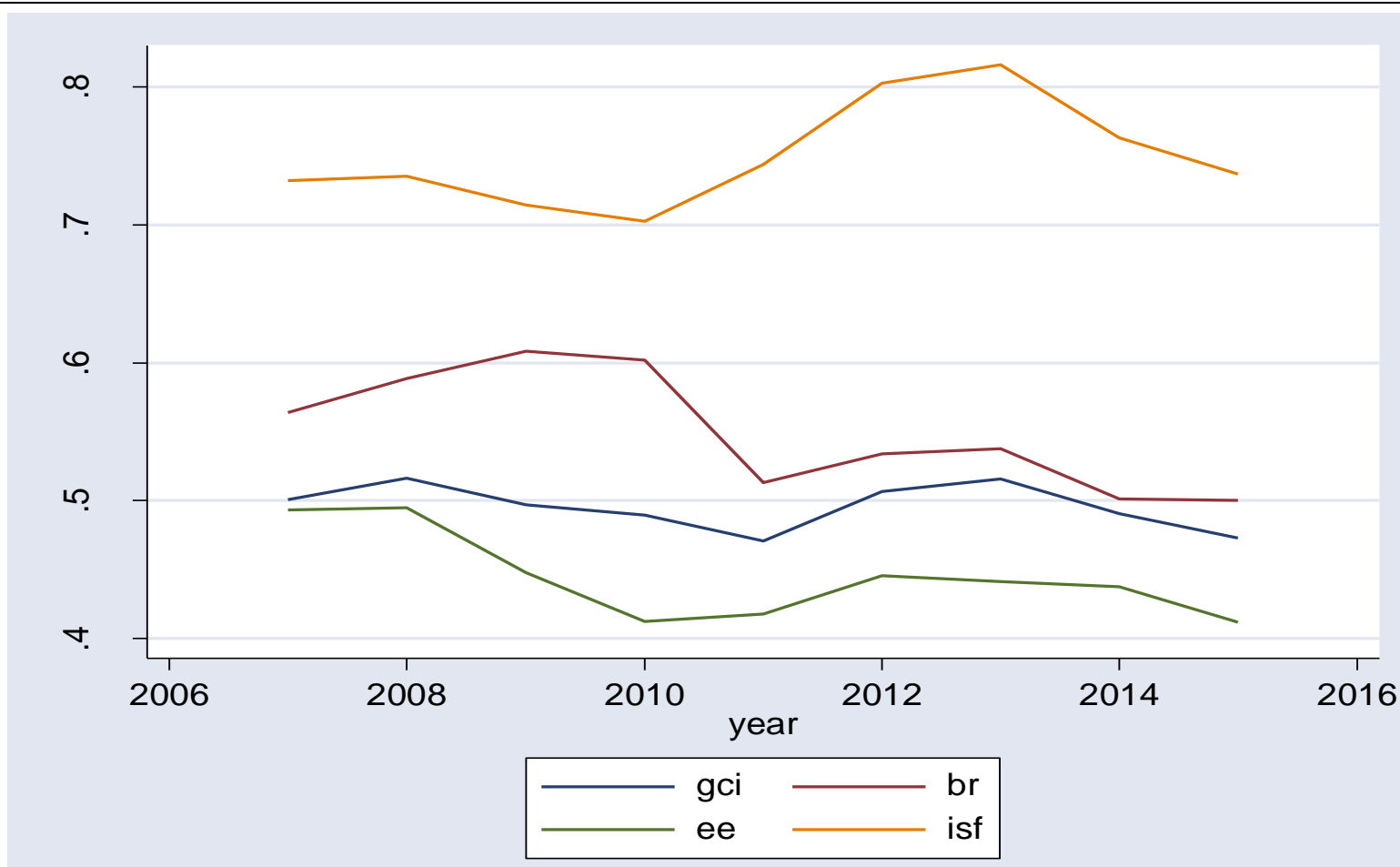

Source: Authors' computations based on Schwab (2015), the World Economic Forum, Global Competitiveness database 2015-2016

\section{The Value of the Global Competitiveness Index (GCI)}

As we indicated, the GCI was formed by the World Economic Forum (WEF) in early 2000 and offers ranking of countries' competitiveness over time. The GCI ranking is based on a set of qualitative and quantitative indicators that comprise the pillars and the sub-indices of the index (World Economic Forum, 2015)

According to the Investment Frontier (2014), there are three ways frontier market investors can use the 2014-2015 Global Competitiveness Report:

1. Global competitiveness index, to identify countries with growth potential, and hence provide guidance on potential investment destinations; as the Investment Frontier recognized, the emphasis is not about ranking of countries as much it is about the progress achieved, considering the stage of economic development of the particular country.

2. Classification of countries by the World Economic Forum, according to specific development stage may help to define frontier markets depending on the main sources of growth for each stage of development.

3. Global competitiveness index, in terms of identifying high performers as well as laggards. This could, however, be complicated without adequate knowledge of the context of countries under consideration and in the absence of a longer time series of the ranking.

However, there are also various limitations to the global competitiveness index, and these include, but are not limited to, the following:

- Given a significant portion of the global data is gathered by executive opinion surveys, certain biasedness may arise due to cross-country variation in willingness to be honest. As argued by 
Sala-i-Martin, et al (2009) in Schwab (2009) the survey data are based on the informed judgments of the actual participants in economies of the countries concerned that include" .While this may reasonably hold true for advanced economies with established democratic system and properly functioning institutions, there is an element of doubt about the validity of the underlining argument regarding the developing and some emerging economies supporting low levels of democracy and openness. As recognized by Sala-i-Martin, et al (2009), the results of the survey compiled from academics and business economists in 2009 showed significance differences in assessing the potential impact of the financial crisis on long-term competitiveness of nations.

- The second and major problem with, not only the GCI, but also other indices for the world economy in general, corresponds to the potential endogeneity or reverse causality between the pillars and sub-indices over time.

Our results, based on a report pertaining to a group of 28 EU member states during the years 20062007 to 2014-2015, point to statistically significant (at 5\% level of significance) correlations between the aggregate indices. We used an econometric software program, Stata, version 8 to run correlation matrices, descriptive statistics and graphs. Figure 5 presents descriptive statistics of the main pillars for the EU 28 countries. From these, it is apparent that the highest level of disparity among the EU 28 countries is with innovation and sophistication factors as indicated with the highest standard deviation (0.73. The correlation matrices of aggregate pillar scores for the $28 \mathrm{EU}$ member states during 20062007 and 2014-2015 periods are summarized in Table 3. The results show a significantly high level of correlation between the scores of the aggregate pillars that result in a challenging task to isolate the direct impact of the scores from their indirect impact on the overall GCI score.

Table 2: Descriptive statistics of the competitiveness variables

\begin{tabular}{|c|c|c|c|c|c|}
\hline Variable & Observations & Mean & Std. Dev. & Min & Max \\
\hline $\begin{array}{c}\text { Global } \\
\text { Competitiveness } \\
\text { Index (GCI) }\end{array}$ & 243 & 4.731 & 0.492 & 3.86 & 5.61 \\
\hline $\begin{array}{c}\text { Basic requirement } \\
\text { (BR) }\end{array}$ & 243 & 5.191 & 0.545 & 4.07 & 6.26 \\
\hline $\begin{array}{c}\text { Efficiency } \\
\text { Enhancers (EE) }\end{array}$ & 243 & 4.689 & 0.429 & 3.83 & 5.69 \\
\hline $\begin{array}{c}\text { Innovation and } \\
\text { Sophistication } \\
\text { Factors (ISF) }\end{array}$ & 243 & 4.368 & 0.735 & 3.2 & 5.79 \\
\hline Sourc Author' conp
\end{tabular}

Source: Authors' computations based on the World Economic Forum, Global Competitiveness database (Schwab, 2015).

Schuller and Lidbom (2009) showed that countries with higher ranking in human development indicators (HDI) are highly correlated with GCI and BCI rankings and that this holds even more so for GDP per capita and GCI. This again somewhat signals a "self-fulfilling prophecy" and permanent divergence in global competitiveness positions of countries, albeit with some exceptions.

Table 3: Correlation matrices of the aggregate pillars scores for EU group, 2006-2007 and 2014-2015

\begin{tabular}{|c|c|c|c|c|}
\hline & $\begin{array}{c}\text { Global } \\
\text { Competitiveness } \\
\text { Index }\end{array}$ & $\begin{array}{c}\text { Basic } \\
\text { Requirement } \\
\text { (BR) }\end{array}$ & $\begin{array}{c}\text { Efficiency } \\
\text { Enhancers (EE) }\end{array}$ & $\begin{array}{c}\text { Innovation and } \\
\text { Sophistication } \\
\text { Factors (ISF) }\end{array}$ \\
\hline $\begin{array}{c}\text { Global } \\
\text { Competitiveness } \\
\text { Index }\end{array}$ & 1.000 & & & \\
\hline
\end{tabular}




\begin{tabular}{|c|c|c|c|c|}
\hline $\begin{array}{c}\text { Basic } \\
\text { Requirement } \\
\text { (BR) }\end{array}$ & $0.927^{*}$ & 1.000 & \\
\hline $\begin{array}{c}\text { Efficiency } \\
\text { Enhancers (EE) }\end{array}$ & $0.976^{*}$ & $0.873^{*}$ & 1.000 & \\
\hline $\begin{array}{c}\text { Innovation and } \\
\text { Sophistication } \\
\text { Factors (ISF) }\end{array}$ & $0.972^{*}$ & $0.905^{*}$ & $0.938^{*}$ & 1.000 \\
\hline $\begin{array}{l}\text { Source: Authors' computations based The World Economic Forum, Global Competitiveness database } \\
\text { (Schwab, 2015) }\end{array}$ \\
\hline
\end{tabular}

Table 4: Descriptive statistics for broader sub-indices for the EU group 2006-2007 to 2014-2015

\begin{tabular}{|c|c|c|c|c|c|}
\hline Variable & Observation & Mean & Std. Dev. & Min & Max \\
\hline $\begin{array}{c}\text { Global } \\
\text { competitiveness index }\end{array}$ & 252 & 4.709 & 0.4973 & 3.86 & 5.61 \\
\hline Institutions (inst) & 252 & 4.594 & 0.848 & 3.05 & 6.18 \\
\hline Infrastructure (infr) & 252 & 4.927 & 0.929 & 2.56 & 6.65 \\
\hline $\begin{array}{c}\text { Macroeconomic } \\
\text { environment (macr) }\end{array}$ & 252 & 4.994 & 0.652 & 2.42 & 6.43 \\
\hline $\begin{array}{c}\text { Health and primary } \\
\text { education (hped) }\end{array}$ & 252 & 6.177 & 0.296 & 5.47 & 6.94 \\
\hline $\begin{array}{c}\text { Higher education and } \\
\text { training (het) }\end{array}$ & 252 & 5.042937 & 0.514 & 3.99 & 6.27 \\
\hline $\begin{array}{l}\text { General market } \\
\text { efficiency (gme) }\end{array}$ & 252 & 4.710 & 0.740 & 3.75 & 14.00 \\
\hline $\begin{array}{l}\text { Labor market } \\
\text { efficiency (lme) }\end{array}$ & 252 & 4.458 & 0.435 & 3.29 & 5.60 \\
\hline $\begin{array}{c}\text { Financial market } \\
\text { development (fmd) }\end{array}$ & 252 & 4.599 & 0.641 & 2.85 & 6.40 \\
\hline $\begin{array}{l}\text { Technological } \\
\text { readiness (tr) }\end{array}$ & 252 & 4.908 & 0.771 & 2.91 & 6.36 \\
\hline Market size (ms) & 252 & 4.306 & 0.924 & 2.16 & 6.02 \\
\hline $\begin{array}{c}\text { Business } \\
\text { sophistication (bs) }\end{array}$ & 252 & 4.661 & 0.678 & 3.40 & 5.99 \\
\hline Innovation (innov) & 252 & 4.013 & 0.828 & 2.90 & 5.79 \\
\hline
\end{tabular}

Source: Authors' computations based on the World Economic Forum, Global Competitiveness database (Schwab, 2015)

Table 6 shows the results of the correlation matrices of the rankings of the sub-indices for a group of 28 EU member states during the 2006-2007 to 2014-2015 periods. From the results in Table 6, there appears a strong and statistically significant correlation (at 5\% level of significance) between the GCI score and other sub-indices scores. On the one hand, this is in line with that expected. On the other hand, a problem exists when most variables (sub-indices) correlate with each other. This problem is the same concern expressed earlier in reference with endogeneity or reverse causality, i.e., difficulty in interpreting results. 


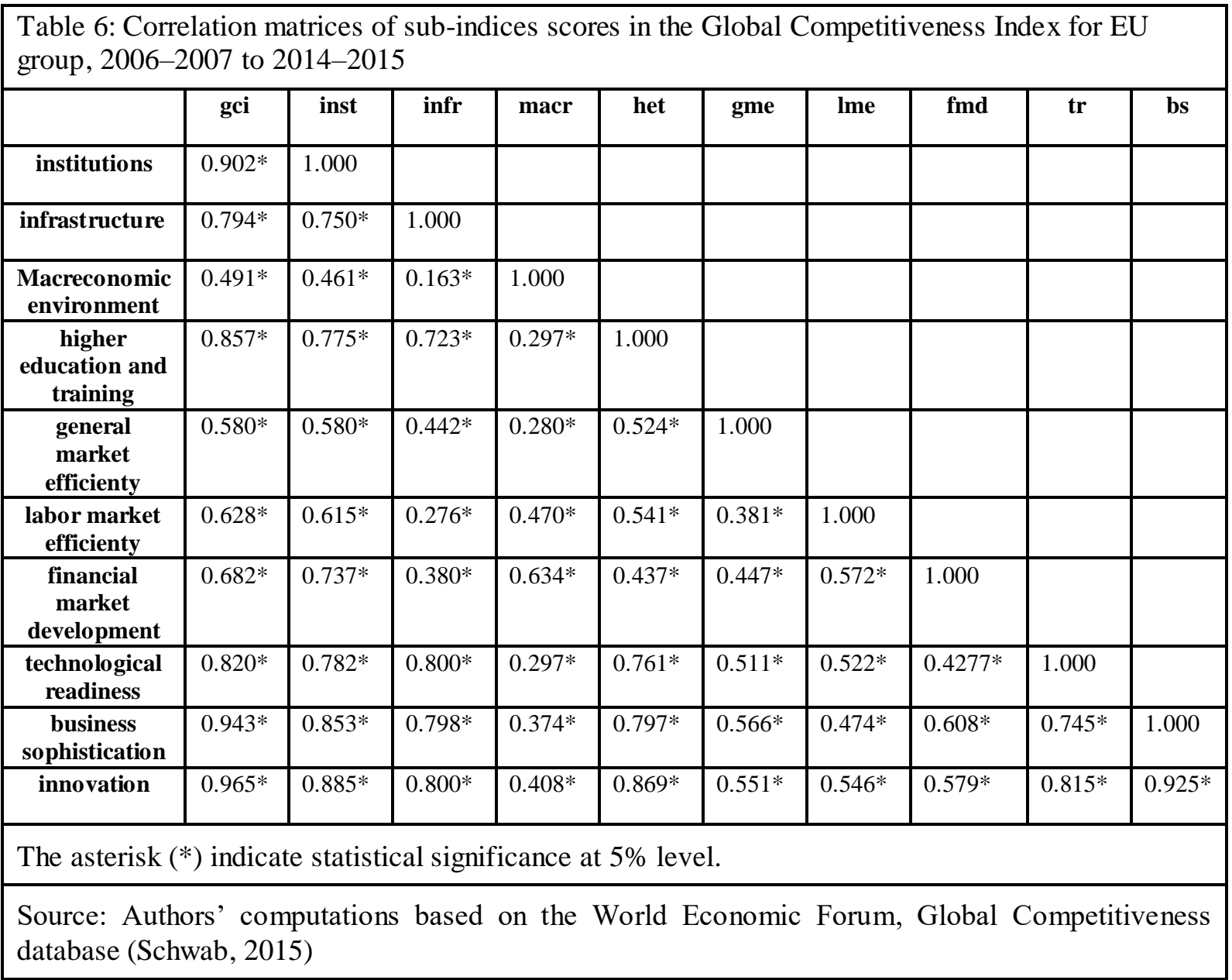

\section{Conclusion}

The results of our study, and others similar, indicate that the European Union (EU) is far from being a homogenous economic club in terms of the global competitiveness index. Although there has been convergence in institutional frameworks and infrastructure, and to a large extent, the macroeconomic environment in the EU, there persists a gaps regarding technology across EU member states.

In respect to the Global Competitiveness Index (GCI), our results suggest difficulties in isolating the impact of pillars and sub-indices in the GCI for proper ranking because of the strong correlations between almost all the underlining variables. Nonetheless, the GCI still serves as a significant global indicator in assessing the potential of countries in terms international trade as well as investments. We argue that it would be more informative to follow the rankings of countries according to sub-indices (based disaggregated data) rather than overall ranking, which may not be as informative in terms of trade and investment decisions. The reason is that it is relative competitive advantage that makes countries better off as no country can achieve the highest competitive advantage in all aspects of the business environment given variation in natural endow ments among other things.

\section{References}

Barro, J. (2003). Determinants of Economic growth in a Panel of Economies. Annals of Economics and Finance, 4, $231-274$.

Blanke, J., Paua, F., and Sala-i-Martin, X. (2009). 'The Growth Competitiveness Index: Analyzing Key Underpinnings of Sustained Economic Growth', in The Global Competitiveness Report: 2004-05, M. Porter et al., (eds), Oxford: Oxford University Press.

Frenkel, M., Koske, I., and Swonke, C. (2003). How Competitive are Europe's Economies? Findings of the Global Competitiveness Report 2002-2003, Inter economics, January/February, 31-37.

Investment Frontier (2014). Three Ways to Use The 2014 Global Competitiveness Report. Retrieved March 30, 2016, from http://www. investmentfrontier.com/2014/09/08/3-ways-use-2014-global-competitiveness-report/

Krugman, P. (1994). Competitiveness: A dangerous obsession, Foreign Affairs, 73 (2) (28-44).

Lall, S. (2001). Competitive Indices and Developing Countries, An Economic Evaluation of the Global Competitiveness Report, World Development, Vol. 29, No. 9 (1501-1525).

Lucas, R. E. (1988). On the Mechanics of Economic Development. Journal of Monetary Economics, 22 (3-42). 
Mankiw, N. G., Romer, D. and Weil, D. N. (1992). A Contribution to the Empirics of Economic Growth. Quarterly Journal of Economics, May. (407-437).

MacArthur, W.J and Sachs, J. (2002). The Growth Competitiveness Index: Measuring Technological Advancement and the Stages of Development. Retrievedhttp://www.walkerd.people.cofc.edu/Readings/Trade/KrugmanDangerous.pdf

Nelson, R. R., and Phelps, E. (1966). Investment in Humans, Technological Diffusion, and Economic Growth, The American Economic Review, Vol. 56, No. 1/2. (69-75).

Porter, M. E. (1990). The Competitive Advantage of Nations. New York: The Free Press.

Romer, P. (1990). Endogenous Technological Change. Journal of Political Economy, 98 (71-102).

Sala-i-Martin, X., J. Blanke, M. Drzeniek Hanouz, T. Geiger, I. Mia, and F. Paua. (2008). The Global Competitiveness Index: Prioritizing the Economic Policy Agenda. In Schwab, K. (2008) Retrieved from http://www3.weforum.org/docs/WEF_GlobalCompetitivenessReport_2009-10.pdf

Schuller, B. J, and Lidbom, M. (2009). Competitiveness of Nations in the Global Economy: Is Europe Internationally Copetitive? Economics and Management, 14 (934-939).

Schwab, K. (2009). The Global Competitiveness Index 2009-2010. World Economic Forum. Retrieved http://www3.weforum.org/docs/WEF_GlobalCompetitivenessReport_2009-10.pdf

Workie Tiruneh, M., and Griffin, D. (2015). Can We Be Competitive without Being Educated? Empirical Findings from European Data. Proceedings from the Annual Conference „Management Challenges in the 21st Century: HR Trends and Challenges: How to Succeed in Turbulent Times. www.cutn.sk/Library/proceedings/mch.../27.\%20Tiruneh_Griffin.pdf Schwab, K. (2012). World Economic Forum, Global Competitiveness Report (2012-2013). Retrieved http://www3.weforum.org/docs/WEF_GlobalCompetitivenessReport_2012-13.pdf

Schwab, K. (2015). World Economic Forum, Global Competitiveness Report (2014-2015) Retrieved http://www3.weforum.org/docs/WEF_GlobalCompetitivenessReport_2014-15.pdf

World Economic Forum, Global Competitiveness database (2015-2016). Retrieved www3.weforum.org/docs/GCR201415/GCI_Dataset_2006-07-2014-15.xlsx 